\title{
Revisiting Privatization and Economic Growth in Malaysia: An Empirical Examination
}

\author{
Fong-Woon Lai ${ }^{1}$, Muhammad Kashif Shad ${ }^{1 *}$, Yeong Yoon Chow ${ }^{2}$, and Chin Yi Wei ${ }^{2}$ \\ ${ }^{1}$ Management and Humanities Department, 32610 Universiti Teknologi PETRONAS Malaysia. \\ ${ }^{2}$ Computer and Information Sciences Department, 32610 Universiti Teknologi PETRONAS, Malaysia.
}

\begin{abstract}
The rapid expansion of the public sector's investment in the early 1970s and 1980s in Malaysia had resulted in a bloated bureaucracy, inefficiency, high costs and low productivity. The emergence of privatization policy in Malaysia aimed to reduce the financial burden of government, increase the level of efficiency and productivity, increase firm's revenue, improve the country's fiscal position and encourage foreign direct investment. Nevertheless, some privatization initiatives are controversial. This paper re- examines the relationship between privatization and economic growth in Malaysia. Two sets of annual macro- economic data from 1984 to 1990 and 2009 to 2015 were used. Descriptive and frequency analysis was used to test the hypothesized relationship between privatization program and its impact on the nation's macroeconomic benefits namely GDP growth, job creation as well as FDI inflows. By looking at the economic data sets, this paper found that the influence of privatization in Malaysia on economic growth, job creation and foreign direct investment inflow varies.
\end{abstract}

Keywords: Privatization, Economic Growth, FDI inflows, Job Creation

\section{Introduction}

Over the last few decades, governments have vigorously and increasingly embraced privatization of state-owned enterprises by shifting responsibility from the state to the private sector (Cook and Uchida, 2003). Privatization notably gained the attention of many countries including Malaysia as a strategy for development. Instead, a more considerable attention was paid in prior studies that attempt to understand and examine the influence of privatization on economic growth in the context of different countries. In 1969, the Malaysian government adopted a New Economic Policy which aimed to reduce poverty. For that, a significant amount of public enterprises were formed as one of the instruments to achieve a redistribution of income within Malaysian society in favor of all communities including Bumiputera. Between the 1970s and 1980s, the Malaysian economy was significantly dominated by public sector entities because a large number of public enterprises were created with the aim of promoting the participation of the Bumiputera community in the economy and achieving socioeconomic objectives of the New Economic Policy. As government intervention in economy increases, the size and the scope of the public sector grew, which led to a corresponding increase in public sector's expenditure and debts over Gross Domestic Product (GDP). Malaysia recorded a government debt equivalent to $80.74 \%$ in 1990 of the country's GDP ${ }^{1}$. The exceptionally high expenditures and debts caused by the expansion of the public sector, coupled with the world economic recession in the early 1980s, had resulted in a dramatic decline in Malaysia's economic growth rate from 6.3\% in 1983 to - 1.1\% in 1985 (Taasim and Yusoff, 2014).

\footnotetext{
1 Trading Economics. https://tradingeconomics.com/malaysia/government-debt-to-gdp (accessed February 27, 2018)
} 
As a result, the Malaysian government was forced to look at its public spending and implement ways to optimize the situation. Embracing privatization appeared to be the most appropriate and suitable solution to solve the problem at hand. Privatization is defined as the process of transferring ownership of an entity or business operations from the state ownership to the privately owned entity (Bakar et al., 2016). In March 1983, Malaysian Prime Minister announced the government's intention to embark on a privatization policy in line with the Malaysia Incorporated Policy hoping that the government's financial burden could be alleviated. Since the announcement of the privatization policy in 1983, there was a significant increase in the number of privatized projects.

Privatization opens up unprecedented opportunities for investment throughout the world. It is a major force in the globalization of business. In the case of Malaysia, privatization has transformed numerous local companies into multinational companies. Nevertheless, despite their potential benefit and value, not all privatization instances achieved their intended objectives.

Considering the various failure and success stories of privatization programs in different countries, this paper aims to investigate the impacts of privatization in Malaysia towards its macroeconomic development in terms of GDP growth, job creation and foreign direct investment (FDI) inflow in the context of encouraging international trade and promoting business globalization.

\section{Overview of Privatization Programs}

Privatization programs have been increasingly implemented all over the world. The wave started in the late 1970s in Chile and the United Kingdom which subsequently had caught on in the former Soviet Union, Eastern Europe, Latin America and India. In the late 1980s and 1990s, as part of its economic reform, China privatized much of its state-owned industry. In the process, the central government lifted price controls, protectionist policies and regulations (Knowledge @ Wharton, 2018).

Privatization has been acknowledged as one of the main contributors that lead to economic development and international trade improvement. It reduces the trade barriers for privatized businesses and allows an increasing number of international businesses which leads to an increase in foreign direct investment. The implementation of privatization programs has created a highly competitive global marketplace. The importance of foreign direct investment cannot be ignored as it is considered as an essential conduit for sustainable economic growth and international competitiveness for a country (Tuzunturk et al., 2016). Based on the World Bank Report (2012) the main target of privatization is to provide inflows of foreign direct investment for many countries. It has also brought positive impacts on financial market development. Many studies show that privatization has contributed to the growth of stock market capitalization and trading all over the world.

Although the trend towards privatization was growing, yet its impact on national development was controversial and still under debate as economic efficiency can only be achieved if privatization initiatives are carried out with robust institutional practice. Some researchers found that privatization catalyzed economic growth (Zhao, 2013). Other researchers, however, argued that the successful implementation of privatization policy was not very affirmative. For instance, privatization in Nepal might not be beneficial in terms of employment opportunities, production and sales, as well as financial profits (Fatta, 1998). India implemented gradual divestment of public enterprises for privatization but criticism was raised due to the slow progress. Several ASEAN countries such as Indonesia, Philippines, and Thailand have experienced only limited success in their privatization efforts (Dholakia and Dholakia, 1994).

The condition for successful privatization is the government's political capacity to plan and implement effective institutional processes required for enforcing compliance with productivity-enhancing regulations. This condition, nonetheless, might not always in place. The noble intention of privatization program for a greater national economic interest was often succumbed to a narrower greed of political rent seeking agenda.

From a micro viewpoint at the firm level, privatization policy in a country is justifiable with its outcomes to deliver desirable results in enhancing companies' performance measured by profitability, productivity, efficiency and leverage. These outcomes are crucial to ensure the solidification of a nation's micro-economic 
foundations in order to support the attainment of macroeconomic objectives of the nation's economic policies (Ramadan, 2011; Nambiar, 2009).

On the flip side, however, privatization programs can be failures and they do happen more often than not. Filipovic, (2006) found a negative relationship between privatization and economic growth. Kwek and Yei, (2007) stated that the privatization of public entities would burden the people if charges were raised for privatized entities. In a nutshell, many instances have indicated that the successful implementation of privatization policies is still short of being affirmative and privatization programs often lead to adverse impact in several countries.

\subsection{Privatization in Malaysia}

The Malaysia government's intention towards privatization emerged in the 1980s through the establishment of Malaysian Incorporated Policy by the then Prime Minister, Dato' Seri Dr. Mahathir bin Mohamad. The initial objective was to alleviate the financial burden of Malaysian government amidst the implementation of New Economic Policy (NEP) which in turn, was aimed at reducing poverty and eliminate inter- ethnic disparities. The huge amount of government's debt in the wake of establishing an increasing number of public enterprises drove the government to transfer public enterprises to private ownership. Thus, the public sector was no longer the prime engine of growth for economic development. The privatization program in Malaysia has significantly impacted its economic reform agenda. It has changed the structure of incentives, reduced government interventions, improved monitoring on the activities of public enterprises and introduced competition to the industry. Hence, privatization has contributed to higher levels of micro-economic efficiency and fostered sustained economic growth (Tan, 2007).

Nevertheless, studies had also shown that the privatization programs in Malaysia might not be all the success stories. Pockets of failure existed and this was particularly due to the lack of improvement on the needed institutional process. Specifically, the privatization policy's aims of reducing the government financial burdens, increasing efficiency of the privatized firms as well as enhancing the country's economic growth have not been fully achieved albeit that its New Economy Policy target of increasing Bumiputera share acquisitions was met (Nambiar, 2009; Masruri, 1996).

\section{Theoretical Framework}

The purpose of privatization in Malaysia was to create the conditions for national unity by reducing poverty and achieving inter-ethnic economic parity, especially between the politically dominant Malays and economically pervasive Chinese (Jomo and Syn, 2005). This affirmative action is usually referred to as 'restructuring society' in the Malaysian discourse. So important was the privatization program that the Chapter 7 in the Eighth Malaysia Plan, which spanned from year 2001 to 2005, was dedicated to justify the rationale of it in the Malaysian economy. It explained the focus of privatization in the Malaysian economy which was to expand the capacities in developing the infrastructure required in order to effectively foster the development of industries and support services. This in turn, would allow the industries and services to provide better comfort and access to the consumers with the support of an appropriate regulatory framework put in place.

To deliberate on the rationales for privatization program, three theoretical principles can be drawn for reference, namely the Property Rights Theory, Principal- agent Theory and Public Choice Theory.

\subsection{Property Rights Theory}

Property rights Theory states that peoples should respect the allocation and protection of the rights of a property in social and economic relations (Rahbar et al., 2012). Privatization transaction usually means selling of existing state-owned enterprises (SOEs) that are still in operation (Bakar et al., 2016). In relation to the Property rights theory, the ownership of the public company shall then be transferred under the property of the private company, it is believed that the form of ownership hold privately by organizations would improve their 
performance and increase Malaysia's firms' competitiveness in the global market. Privatizing the public enterprises, definitely, affects the political and social factors which we are implicating the five main privatization objectives as stated in the Malaysian Privatization Master Plan (PMP). Furthermore, Moshiri and Abdou, (2010) stated that property rights theory is the most important economic institution. To achieve the long-term perspective of privatization, a nation needs a development-compatible institutional framework that includes well-specified property rights structure. The exclusive rights in making choice on the usage of resources and to service the resources as well as to exchange the resources at mutually agreeable terms should be included in the institutional framework (Moshiri and Abdou, 2010).

\subsection{Principal-Agent Theory}

According to the fundamental privatization theorem, the government shall select private firm through an auction system in order to achieve the efficiency and equity goals (Cavaliere and Scabrosetti, 2008). By referring to the Principal-Agent theory, Cavaliere and Scabrosetti (2008) also claimed that the equation of compensation scheme $\mathrm{P}(\mathrm{z})=\mathrm{V}(\mathrm{z})$ could be the requirement for the government in opting a private firm to take over the business. On the other hand, privatization has created a new agency relationship which the agency theorists argue that new owners must be concerned with managerial perquisite consumption and entrenchment problems of the enterprises (Dharwadkar et al., 2000). Buying over the public enterprises will incur agency costs for the purpose of monitoring the actions of management or in implementing the incentive system to ensure the management is working towards the enterprise goal.

\subsection{Public Choice Theory}

According to Rahbar et al., (2012), the management of public enterprises has no right to claim for the company's revenue thus there is a lack of motivation on managerial efficiency. Based on the Public Choice theory, it is assumed that the internal motives of individuals are the reason they seek for appropriate maximization of the desirability of the owners of companies. The point which makes a difference between private and public companies is that moral hazard and adverse selection are less likely in the private companies. External mechanisms and internal mechanisms are used to minimize such problems (Rahbar et al., 2012). Moreover, Wright (1993) stated that Public Choice theory is "the economic analysis of political institutions". He stated that this theory claims people are rational self-maximizers and this characteristic reflects not only by the peoples who seek to maximize their individual satisfaction, but also the legislators and bureaucrats who seek for the same. In turn, it makes it impossible for the government to act in the public interest.

\section{Conceptual Framework}

Numerous empirical studies have been conducted to examine the success of privatization in relation to the achievement of the targeted micro- and macro-economic objectives. The studies have delivered mixed results in terms of the relationship between privatization and economic growth. As such, the study in this context is by no mean conclusive and exhaustive. Further studies are justified to examine pertinent variables that can potentially impact privatization programs' outcome. Findings can then be interpreted by drawing them to the relevant theories.

This paper undertook to reexamine the phenomena of privatization program of public enterprises in Malaysia and to provide a fresh narrative by relating the executed privatization initiatives to several specific macroeconomic outcomes amidst the influence of globalization facing the privatized enterprises. These outcomes are GDP growth, jobs creation and foreign direct investment (FDI) inflows into the country. The conceptual framework for this paper's reexamination of Malaysian privatization program is depicted in Figure 1. 


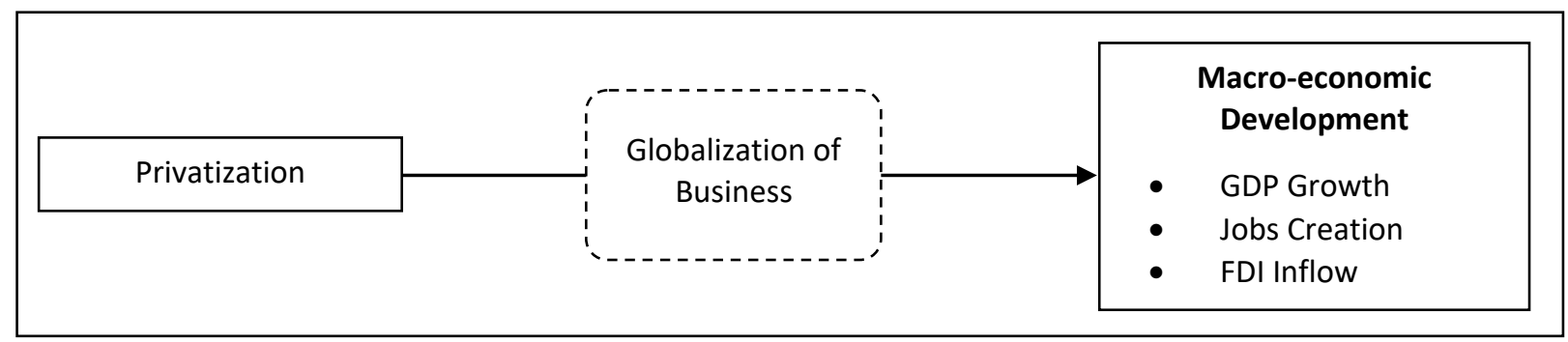

Figure.1: The Conceptual Framework

\section{Hypothesis Development}

In light of the conceptual framework presented above, several hypotheses are formulated to investigate the impact of privatization on macroeconomic development in Malaysia. These hypothesis statements are as below.

\subsection{Gross Domestic Product Growth}

Gross domestic product (GDP) is a significant proxy for investigating the economic growth of any country. Private sector participation is of unique importance in attaining future economic growth and flourishing industrial sector of a particular country (Mehmood and Faridi, 2013). Privatization is likely to enhance the profit streams of the privatized entities whilst reducing government's debt burden of running them (Vickers and Yarrow, 1991). Furthermore, the government can capitalize the earned profit and raise immediate revenue from tax collections and dividend payments. By allocating public and government ownership to the private sector, it is generally believed that the private sector has a higher motivation to generate revenue and create jobs, hence contributing to GDP growth. As such, this paper formulates the hypothesis that:

\section{$H_{1}$ : There is a positive correlation between privatization and GDP growth.}

\subsection{Jobs Creation}

Numerous empirical studies and economic theory posit that the privatization of public enterprises in a country will cut jobs and wages (Earle, 2014). Nonetheless, this may be an exception or a temporary phenomenon. In the greater scheme of things, there is a more likelihood that the private owners may expand their businesses on a large scale which would have the potential to enhance the productivity and create more jobs in the country. The key objective of privatization in Malaysia was to reduce poverty, provide more jobs and eliminate interethnic disparities by increasing share acquisitions. Masruri (1996) mentioned that privatization policy in Malaysia had been successful in achieving the New Economy Policy (NEP) target in which Bumiputera were greatly involved in businesses and more job opportunities were provided to them. Based on these arguments, we hypothesize that:

\section{$\mathrm{H}_{2}$ : There is a positive correlation between privatization and job creation.}

\subsection{Foreign Direct Investment Inflows}

Privatization of various sectors such as energy, banking, telecommunication, manufacturing as well as construction to foreign investors facilitates international trade and FDI inflows. It is expected that privatization would be a major force in encouraging investment throughout the world and the globalization of business. This transforms numerous local companies into multinational companies. The transformation of local companies to multinational companies will not only intensify growth in exports but it will also create more investment opportunities. Moreover, according to Hunya (2000), the primary motivation of FDI in a country appears as a 
result of the globalization of the businesses worldwide. Based on these arguments this study formulates the hypothesis that:

\section{$H_{3}$ : There is a positive correlation between privatization and Malaysia's FDI inflows.}

\section{Research Methodology}

Economic data of Malaysia's GDP, unemployment rate and FDI inflows was collected from the Economic Planning Unit (EPU) of Malaysia, The World Bank DataBank as well as Trading Economics Malaysia. Two sets of sampled data comprising annual observations were extracted for the year 1984 to 1990 and 2009 to 2015. The first set of data involved the period immediately after the execution of privatization program (1983-1984) and prior to the occurrence of the Asian financial crisis (1997-1998). The second set of data involved the period after the happening of global recession (2007-2008). Descriptive and frequency analysis was used to test the hypothesized relationship between privatization program and its impact on the nation's macroeconomic benefits namely GDP growth, job creation as well as FDI inflows.

\section{Results and Discussions}

\subsection{Privatized Projects in Malaysia (1983-2015)}

Table 1 displays the accumulated number of privatized projects which made up of new privatized projects and existing privatized projects each year from 2009 to 2015. The number of new projects being privatized in each year had been steadily increasing since 1990 and reached 165 in 2010. It is worth noting that the number saw a sharp drop to just 25 in 2011. This significant reduction in the privatized projects might be the effect of a setback in the general election performance of the ruling parties in 2008 considering a lagging effect in the privatization policy making and execution. In the 2008 general election, the ruling coalition did not win a twothirds super-majority in the Malaysian Parliament. Privatization decisions by the government have always been sensitive matters in the political climate of Malaysia.

There were just 36 privatized projects in the first phase of Malaysia's privatization program during the period of 1983 to 1990 . The number of total privatized projects had increased to 503 by 2009 and further to 754 by 2015. The number of total privatized projects from 2009 to 2015 represents an average growth rate of $7 \%$.

The increasing number of privatized projects indirectly indicates the improved productivity of privatized firms in handling projects which contribute to Malaysian economic growth. Based on the Property Rights theory, the form of ownership is the predominant explanation for the varying performance of public-owned organizations and privatized organizations. The shift of ownership from government to private sector translates into management's motive to contribute to the organization in order to create value and profits. The efficient and effective corporate control consistently increases firms' productivity and thus the increased ability to take up more projects.

Table 1: Total Number of Privatized Projects in Malaysia

\begin{tabular}{|c|c|c|c|}
\hline Unit & Existing projects & New projects & Total projects privatized \\
\hline $\mathbf{1 9 8 3 - 1 9 9 0}$ & - & - & 36 \\
\hline $\mathbf{2 0 0 9}$ & 348 & 155 & 503 \\
\hline $\mathbf{2 0 1 0}$ & 348 & 165 & 513 \\
\hline $\mathbf{2 0 1 1}$ & 513 & 25 & 538 \\
\hline $\mathbf{2 0 1 2}$ & 538 & 54 & 592 \\
\hline $\mathbf{2 0 1 3}$ & 592 & 49 & 641 \\
\hline $\mathbf{2 0 1 4}$ & 641 & 57 & 698 \\
\hline $\mathbf{2 0 1 5}$ & 698 & 56 & 754 \\
\hline
\end{tabular}




\subsection{Hypotheses Examination}

\subsection{1 $H_{1}$ Examined}

From Table 2, the statistics indicate that the gross domestic product (GDP) growth rate of the Malaysian economy after commencing privatization program in 1983 demonstrated a mixed result in two sets of data observation, i.e. 1984-1990 and 2009-2015.

For instance, in the first set of data from years 1984 to 1986, there were two consecutive periods of negative GDP growth, registering $-7.8 \%$ and $-11.2 \%$ respectively. In the subsequent years until 1990 however, the GDP saw a remarkable growth, averaging the annual growth rate to $12.3 \%$ for the five-year period under study. In terms of quantum, the Malaysian GDP had increased from USD33.9 billion in 1984 to USD44 billion in 1990, representing a compounded annual growth rate of $4.4 \%$ in the period under examination. In the second data set of observation from 2009 to 2015 on the other hand, there was a period of negative GDP growth of 12.4\%, i.e. 2014-2015. The remaining periods only registered a comparatively meagre GDP growth ranging from $2.9 \%$ to $5.4 \%$ as compared to years 1984-1990. For the entire duration, the country's GDP growth registered a compounded annual growth rate of only $0.7 \%$ albeit in the absolute terms, the GDP has grown to USD310 billion in 2015.

With the above descriptive statistical examination, the study concludes that the below hypothesis where:

\section{$H_{1}$ : there is a positive correlation between privatization and GDP growth;}

is rejected!

\subsection{2 $\mathrm{H}_{2}$ Examined}

Prevailing economic theory posits that the privatization program cut jobs and wages. Nonetheless, this ignores the possibility that privatization program allows new owners to expand the business at a broader level with potentially positive effects on creating jobs.

To examine the above argument, the statistics from Table 2 indicate that the unemployment rates in Malaysia after commencing privatization program in 1983 demonstrated an upward trend from 1984 to 1998 before tapering off. The unemployment rates were rather high touching $8.3 \%$ in 1986 . This scenario seems to support the notion that privatization led to jobs cutting from the observation of the first set of data (1984-1990) under study.

It can be argued that the sharp rise in unemployment was due to the series of inverse macroeconomic shocks, partly self-inflicted by bad policies or unfavourable international developments. Privatized entities succumbed to complex market conditions and challenging operating environment in the midst of business liberalization and international trade globalization process.

The high rates of unemployment exhibited a glaring fall after 1990. The second set of data in Table 2 attests that unemployment rates remained low hovering in the range of $2.9 \%$ to $3.5 \%$ from the years 2011 to 2015. The average annual unemployment rate during this seven-year period was $3.2 \%$, a stark contrast to that of $7.1 \%$ for the years 1984 to 1990. The fall in unemployment rate after the 1990s reflected an improved learning curve of Corporate Malaysia in dealing with the challenges brought about by business liberalization and international trade globalization, within which many of its constituents were the privatized public enterprises who made up of a significant size as employers in the Malaysian economy and many of which until today still remain as important government-linked companies (GLCs), economically and politically.

Whereas the scrutinization of the unemployment data for the years 1984 to 1990 does not support the notion that privatization has a positive correlation with job creation, statistics for the years 2011 to 2015 are in favor of the employment argument, hence a mixed result. Further deliberation would suggest that perhaps job creations would be influenced more directly by how well the privatized enterprises and corporate Malaysia in 
general would face up the challenges brought by, as well as to seize the opportunities offered by, the liberalized and globalized market place. Thus, the below hypothesis where:

\section{$\mathrm{H}_{2}$ : There is a positive correlation between privatization and job creation;}

is rejected!

\subsection{3 $\quad \mathrm{H}_{3}$ Examined}

Privatization is a major force in encouraging investment throughout the world and the globalization of businesses. From Table 2, the statistics indicate that the foreign direct investments (FDI) inflows in the Malaysian economy after commencing privatization program had revealed a gradual increment from 1984 to 1990 albeit the trend was not perfectly linear. The country's FDI inflows grew from USD1.26 billion in 1984 to USD6.3 billion in 1990, registering a compounded annual growth rate of $31 \%$. The entire period attracted an accumulated FDI inflows of USD40.34 billion, equivalent to an annual average FDI inflow of USD5.76 billion.

In the second data set of observation from the year 2009 to 2015 on the other hand, FDI inflows saw a rather roller-coaster trend. The entire seven-year period attracted an accumulated FDI inflows of USD83.1 billion, equivalent to an annual average FDI inflow of USD11.9 billion.

These figures are slightly more than double those of in the first set of data observation from 1984 to 1990.

Malaysia was one of the highest recipients of foreign investment in the region during this period. According the Malaysian Investment Development Authority (MIDA), the largest part of the investment in this period came from China, Singapore, Switzerland, Holland and Germany. With this descriptive statistical examination, the study concludes that the below hypothesis where:

\section{$H_{3}:$ There is a positive correlation between privatization and Malaysia's FDI inflows;}

is accepted!

Table 2. Macroeconomic benefits of Privatization

\begin{tabular}{|c|c|c|c|c|c|c|c|c|c|c|c|c|c|c|}
\hline \multirow{2}{*}{ Factors } & \multicolumn{7}{|c|}{ 1984-1990 } & \multicolumn{7}{|c|}{ 2009-2015 } \\
\hline & 1984 & 1985 & 1986 & 1987 & 1988 & 1989 & 1990 & 2009 & 2010 & 2011 & 2012 & 2013 & 2014 & 2015 \\
\hline $\begin{array}{l}\text { GDP (US \$) } \\
\text { (Billion) }\end{array}$ & 33.9 & 31.2 & 27.7 & 32.1 & 35.2 & 38.8 & 44.0 & 298 & 314 & 323 & 338 & 296 & 296 & 310 \\
\hline $\begin{array}{l}\text { GDP Growth } \\
\text { Rate }(\%)\end{array}$ & - & -7.8 & -11.2 & 15.9 & 9.7 & 10.2 & 13.4 & - & 5.4 & 2.9 & 4.6 & -12.4 & 0 & 4.7 \\
\hline $\begin{array}{c}\text { Unemployment } \\
\text { Rate }(\%)\end{array}$ & 6.1 & 6.9 & 8.3 & 8.2 & 8.1 & 6.7 & 5.1 & 3.3 & 3.1 & 2.9 & 2.9 & 3.2 & 3.5 & 3.4 \\
\hline $\begin{array}{l}\text { FDI Inflows } \\
\text { (US \$) (Billion) }\end{array}$ & 1.26 & 7.9 & 6.9 & 4.2 & 7.1 & 6.68 & 6.3 & 15.1 & 9.1 & 11.3 & 10.6 & 9.9 & 13.1 & 14.0 \\
\hline
\end{tabular}

Source: Adopted from the World Bank

\section{Future Research}

Many research studies point to the growing trend of privatization globally in achieving economic development. Further works can be done to have a more in-depth and comprehensive analysis on the impacts of privatization in all aspects of Malaysian economy, be it at the macro or micro level. For instance, latest data related to privatization achievement in Malaysia can be collected from the Economic Planning Unit (EPU), Bank Negara Malaysia, International Monetary Fund (IMF) and World Development Report for further interpretation. 
Future research can also be undertaken to look into the roles of institutional changes and practices with regard to the attainment of full benefits of privatization program. Several major privatization failures in Malaysia can be case-studied in the context of the existing institutional framework that they were operating in.

Furthermore, comparative studies can be performed to analyze the socioeconomic performance of Malaysia's privatization program against those in other ASEAN countries such as Thailand, Indonesia, Philippines and Vietnam. This is to gain insights into the efficacy of different privatization policies implemented in these countries as compared with Malaysia.

\section{Conclusion}

Malaysia's privatization policy implementation reached its height in the 1990s during when the then prime minister announced his Vision 2020 in February 1991 for the nation to achieve developed country status by the year 2020. In the same year, the government issued its Privatization Master-plan, including a Privatization Action Plan. The Malaysia vision 2020 was imperative to ensure the onward economic development of the country since 1990. In order to achieve the aspiration of vision 2020, Malaysia needed to be transformed into a form of dynamism and productivity. Realizing the fact that privatization would result in a higher level of economic growth in Malaysia, robust privatization programs were actively undertaken in order to create a private sector-led economy.The role of government in business could be rationalized by continuously increasing privatization and establishing a facilitation fund for the fully-private sector, public-private partnerships (PPPs) and government- linked companies (GLCs). From a macroeconomic perspective, privatization provided a platform that opened up unprecedented international business opportunities. Privatized entities were exposed to an increased number of international trade and foreign investments which at the same time, increased Malaysia's foreign direct investment inflows. Privately-owned enterprises were allowed to implement their way of conducting business without much intervention from the government in their daily business operations. This had provided greater autonomy for privatized companies to expand their business internationally.

The globalization of business could help increase privatized enterprises' revenue and their corporate tax return to the government's coffer. Nonetheless, the full benefits of privatization could only be achieved with the reformation of institutional processes to ensure that appropriate regulatory framework was in place in order to safeguard consumers' interests and monitor the performance of privatized entities.

By looking at the economic data sets for the periods from 1984-1990 and 2009-2015, this paper found that the influence of privatization in Malaysia on economic growth, job creation and foreign direct investment inflow varies.

\section{References}

R. Bakar, R.N.D.N. Darwazeh, and W.S. Sakinah, "Privatization effects on Zakat and dividend: Empirical evidence from Malaysia and Jordan." Journal of Entrepreneurship, Business and Economics, 4(1), 1-21, (2016).

A. Cavaliere, and S. Scabrosetti, "Privatization and efficiency: from principals and agents to political economy". Journal of Economic Surveys, 22(4), 685-710, (2008).

P. Cook, and Y. Uchida, "Privatisation and economic growth in developing countries". The Journal of Development Studies, 39(6), 121-154, (2003).

B. Dharwadkar, G. George, and P. Brandes, "Privatization in emerging economies: An agency theory perspective". Academy of management Review, 25(3), 650-669, (2000).

B.h. Dholakia, and R.H. Dholakia, "Malaysia's privatization programme". Vikalpa, 19(3), 25-36, (1994).

J.S. Earle, "Impact of privatization on employment and earnings". IZA World of Labor, (2014)

B. Fatta, "Impact of Privatization in Nepal". Nepal Commerce Campus: Economic Review, pp. 15-34, (1998).

A. Filipovic, "Impact of privatization on economic growth". Undergraduate Economic Review, 2(1), 7, (2006). 
T. Hassan, M.K. Hassan, M. Ariff, and S.M.R. Mohd, "Productive Efficiency and Welfare Gains from Privatization in Malaysia". Journal of Economic Cooperation \& Development, 36(1), (2015).

G. Hunya, "The relationship between FDI, privatization and structural change in Central and Eastern European countries". Privatization, Corporate Governance and the Emergence of Markets, pp. 189-204 (2000).

K. Jomo, and T.W. Syn, "Privatization and re-nationalization in Malaysia: A survey". Paper presented at the Expert Group Meeting on Re-inventing Public Enterprise and its Management, (2005).

Knowledge @ Wharton, The Long and Winding Road to Privatization in China, [Online]. Available from http:// knowledge.wharton.upenn.edu/article/the-long-and- winding-road-to-privatization-in-china/ [2018, March 01], (2018).

S.W. Kwek, and N.S. Yei, "Privatization in Malaysia. Malaysian Economy: An Overview" http://www.harwaimun.com/privatization.html, (2007).

M. Masruri, "Malaysian privatization: its impact on public finance, efficiency, economic growth and the new economic policy". University of East Anglia. (1996).

K.A. Mehmood, and M.Z. Faridi, "Effects of privatization on economic performance in Pakistan". Middle-East Journal of Scientific Research, 16(5), 729-743, (2013).

S. Moshiri, and A. Abdou, "Privatization, Regulation, and Economic Growth in Developing Countries: An Empirical Analysis". International Journal of Interdisciplinary Social Sciences, V- 5-3, (2010).

T. Nambiar, "Revisiting Privatisation in Malaysia: the Importance of Institutional Process". Asian Academy of Management Journal, 14(2), (2009).

F. Rahbar, M. Sargolzaei, R. Ahmadi, and M. Ahmadi, "Investigating the Effects of Privatization on the Economic Growth in Developing Countries: A Fixed Effects Approach". Journal of Economics and Sustainable Development, 3(4), 61-66, (2012).

M. Ramadan, "The Impact of Strategic Partner on the Financial Performance and Operational Performance and Investment Attractiveness of the Company "A study on Jordanian Companies Entered into Strategic Partnership" working paper. Middle East University, (2011).

S.I. Taasim, and R. Yusoff, "Telecommunications Infrastructure Consequence to Economic Growth in Malaysia: Time Series Analysis". International Journal of Computer Trends and Technology (IJCTT), V-18- 5, (2014).

J. Tan, "Privatization in Malaysia: Regulation, rent- seeking and policy failure". Routledge, (2007).

U. Tuzunturk, B. Inam, and F. Giray, "Analyzing the relationship between foreign direct investment and privatization in the European Union Founder Nations by using panel data approach". Panoeconomicus (00), 1-1, (2016).

J. Vickers, and G. Yarrow, "Economic perspectives on privatization". The Journal of Economic Perspectives, 5(2), 111132, (1991).

M.D. Wright, "A Critique of the Public Choice Theory Case for Privatization: Rhetoric and Reality". Ottawa L. Rev., 25, 1 , (1993).

S. Zhao, "Privatization, FDI inflow and economic growth: evidence from China's provinces, 1978-2008". Applied Economics, (2013). 